\title{
Research on the use of Ferro-Chrome slag in civil engineering applications
}

\author{
Khalifa S. Al-Jabri \\ Sultan Qaboos University, Department of Civil and Architectural Engineering, Al-Khod, Oman
}

\begin{abstract}
Over recent decades there has been rapid increase in the industrial waste materials and by-products yields due to the progressive growth rate of population, development of industry and technology and the growth of consumerism. With the growing environmental pressures to reduce waste and pollution, Intensive research studies have been conducted to explore all suitable reuse methods. Wastes such as construction waste, blast furnace, steel slag, coal fly ash and bottom ash have been approved in many places as alternative materials in bridges, roads, pavements, foundations and building construction. The use of industrial solid waste as a partial replacement of raw materials in construction activities not only saves landfill space but also reduces the demand for extraction of natural raw materials. Ferrochrome slag is a by-product from the production of chrome. There are environmental and economic advantages in seeing slags as a potentially useful resource rather than as waste products. Slag management at ferrochrome producing companies has been influenced by the limited space available and financial cost implications of the slag dumps. Internationally, e.g. South Africa, India, Norway, Turkey, East Europe, China, Sweden and USA, ferrochrome slag is used commercially in the road and construction Industries. This material is being used for road construction, as aggregates in concrete industry, brick manufacturing, and in pavement construction as engineering fill and has recently been tried in cement. This paper presents an overview of the recent advances of the use of ferrochrome slag in various civil engineering applications such as road construction, and cement and concrete industries.
\end{abstract}

\section{Introduction}

The greatest user of natural resources is the rapid developing sector of the construction industry. This raises very important concerns on the depleting of these resources at an alarming rate which causes serious threats to the environmental balance. Due to the increase in the world populations, the rapid growing of the industrial, domestic, commercial and technological activities, the associated generation of the solid wastes are increasing substantially creating an additional burden on the environment. The solid waste materials generating from industries are not only occupying valuable land mass but also polluting the environment and creating real challenges to the safe disposal. The best strategy for solid waste management is to work towards achieving the $5 R$ s of reduction, recovery, recycling, reuse, and research [1]. Industrial By-products generated from different industries are creating environmental problems associated with disposal and pollution. However, such materials can be used in manufacturing fireproof materials, used in concrete as partial substitutes for cement and/or sand or they can be added to clay and heat-treated to produce building materials such as ceramic tiles, refractory and insulation bricks and as a material in road construction.
The generated industrial by-products in Oman have increased substantially in the last decade due to the rapid development in the industrial projects, and mining industries. Accumulation and lack of proper disposal strategies of such materials are posing environmental, pollution and health problems. Copper slag (CS), Cement By-pass Dust, CBPD (also called Cement Kiln Dust), Spent Catalyst (SC), and Ferrochrome (FeCr) slag are industrial by-products produced from the process of manufacturing copper and Portland cement, in oil refinery's processes, and chrome, respectively. In Oman, large quantities of copper slag $(60,000$ tons/year), cement by-pass dust (25,000 tons/year), spent catalyst (7300 tons/year) and ferrochrome slag (355,000 tons/year) are produced, most of which is not effectively utilized and disposed on-site without any reuse. The generation of such materials are expected to increase in the future.

The use of the industrial slag products such as $\mathrm{FeCr}$ slag in beneficial applications such as materials in building and road construction reduces the depletion of the natural resources and it results in positive environmental effects. The $\mathrm{FeCr}$ slag possesses physical properties similar to natural aggregates which makes it a suitable material for civil engineering applications. This paper presents an overview of the recent advances of the 
use of ferrochrome slag in various civil engineering applications such as road construction, and cement and concrete industries.

\section{Ferrochrome (FeCr) Slag}

Ferrochrome $(\mathrm{FeCr})$ slag is by product from the production of Ferrochrome, an essential component in stainless steel industry [2]. An amount of 1.1 to 1.6 ton of slag is produced for each ton of $\mathrm{FeCr}$ [3]. In Oman, there are two $\mathrm{FeCr}$ plants that produce about 355,000 tons of FeCr slag annually [4].

$\mathrm{FeCr}$ metal is produced in electric-arc furnaces by a physical -chemical process from the oxide of chromium ore with coke as a reducing agent at temperatures between $1,500^{\circ} \mathrm{C}$ to $1,700^{\circ} \mathrm{C}$. Both the molten $\mathrm{FeCr}$ and the slag flow out into ladles. After gravity separation from the metal, the molten slag, slowly cools in the air, forming a stable and dense crystalline product having an excellent mechanical properties similar to basalt $[5,6]$. The granulated slag (size less than $4.75 \mathrm{~mm}$ ) samples result from water cooling of the slag whereas lumped slag (size between 8 to $20 \mathrm{~mm}$ ) samples produced when slag is air-cooled [7]. The FeCr slag is classified as ferrous slag under iron-alloy slags [6].

Fairly small amount of this material is used in useful applications whereas the vast majority of the material produced annually is disposed of site without further reuse.

\section{Properties Ferrochrome (FeCr) Slag}

The chemical composition of $\mathrm{FeCr}$ slag includes three major elements: Silicon (Si), Aluminium (Al), and Manganese $(\mathrm{Mg})$. Together with their oxides, these components make up $83 \%$ of the slag. The slag also includes oxides such as $\mathrm{Cr}, \mathrm{Ni}, \mathrm{Fe}$ and $\mathrm{Ca}$. Analysis of $\mathrm{FeCr}$ slag generated in Oman showed that it contains 5-6 wt $\% \mathrm{Cr}_{2} \mathrm{O}_{3}, 23-24$ wt $\% \mathrm{Al}_{2} \mathrm{O}_{3}, 22-23 \% \mathrm{MgO}, 34-35$ wt. $\% \mathrm{SiO}_{2}, 1-4$ wt $\% \mathrm{CaO}$ and $4-5$ wt $\% \mathrm{NiO}[4,8]$. The free and combined limes contribute to nearly $3 \%$ of the chemical composition of $\mathrm{FeCr}$ slag and the summation of silicon, aluminium and iron oxides is about $60 \%$ which less than $70 \%$ which is required in order to classify this material as a pozzolanic material. This indicates that $\mathrm{FeCr}$ is not chemically reactive material to be used as cementitious material in lieu of cement since sufficient quantity of lime must be available in order to reach the required rate of hydration and to achieve the required early age strength.

Also, $\mathrm{FeCr}$ slag contains high percentage of Magnesium oxide $(\mathrm{MgO})$ of about $34-35 \%$ which can have an adverse effect in concrete made with $\mathrm{FeCr}$ slag as cement substitute and limit the use of $\mathrm{FeCr}$ slag in rigid pavements [9]. The existence of $\mathrm{MgO}$ in large quantities can retard the initial hydration of cement and increase its setting time [10] as well as causing large changes of volume of about $10 \%$ in concrete and asphalt mixes [11]. However, this adverse effect can be eliminated by slag weathering in atmospheric conditions [11].
Studies [5,6,8,12-15] reported that $\mathrm{FeCr}$ slag possesses excellent physical properties compared to other aggregate since it has good adhesion and good abrasion, has a rough and porous surface (figure 1) and it lacks clay and organic ingredients in tis composition. However, the water absorption rate is relatively high due to the porous nature of the slag.

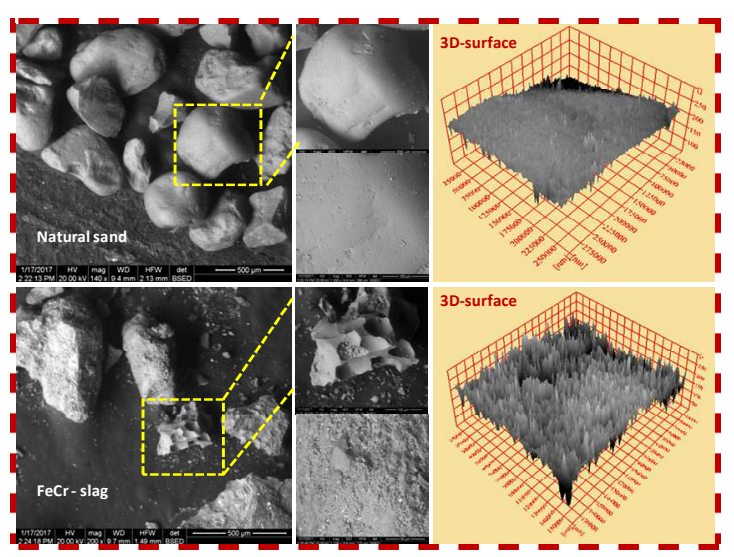

Fig. 1. SEM micrographs and 3D-surface topography images of sand and FeCr-slag [8].

Results from tests conducted by several researchers to determine the physical properties of $\mathrm{FeCr}$ slag indicated that the specific gravity of the $\mathrm{FeCr}$ slag ranges between 2.84 and $3.15 \mathrm{~g} / \mathrm{m}^{3}$ compared with $2.65 \mathrm{~g} / \mathrm{m}^{3}$ for limestone aggregate. While it has water absorption values between $0.25 \%$ and $2.3 \%$ in comparison with $0.38 \%$ for limestone aggregate. The Los Angeles Abrasion and $\mathrm{CBR}$ values of $\mathrm{FeCr}$ slag are between 14$18 \%$ and $107-140 \%$ compared with $21 \%$ and $103 \%$ for limestone aggregate, respectively.

Table 2. Physical properties of $\mathrm{FeCr}$ slag generated in Oman and natural aggregates [4].

\begin{tabular}{|l|l|l|l|}
\hline Property & $\begin{array}{l}\text { FeCr } \\
\text { Slag }\end{array}$ & \multicolumn{2}{|l|}{ Aggregates } \\
\cline { 3 - 4 } & Coarse & Fine \\
\hline $\begin{array}{l}\text { Specific Gravity } \\
\text { g/cm }\end{array}$ & 2.84 & 2.83 & 2.7 \\
\hline $\begin{array}{l}\text { Water Absorption } \\
(\%)\end{array}$ & 0.63 & 0.20 & 0.73 \\
\hline $\begin{array}{l}\text { Flakiness Index } \\
(\%)\end{array}$ & 9.83 & 18.50 & \\
\hline $\begin{array}{l}\text { Elongation Index } \\
(\%)\end{array}$ & 10.50 & 13.5 & \\
\hline $\begin{array}{l}\text { Impact Value (\%) } \\
\text { (mplue }\end{array}$ & 11.00 & 15.30 & \\
\hline $\begin{array}{l}\text { Crushing Value } \\
(\%)\end{array}$ & 17.89 & 20.10 & \\
\hline $\begin{array}{l}\text { Abrasion } \\
\text { Resistance (\%) }\end{array}$ & 18.19 & 18.60 & \\
\hline
\end{tabular}

Also, figure 2 shows that the XRD pattern of $\mathrm{FeCr}$ slag indicates the presence of dominant mineral phases like metalic phase of magnesiochromite $\left(\mathrm{MgCr}_{2} \mathrm{O}_{4}\right)$, chromoferide, silicate phases like forsterite $\left(\mathrm{Mg}_{2} \mathrm{SiO}_{4}\right)$, and Fayalite $\left(\mathrm{Fe}_{2} \mathrm{SiO}_{4}\right)$ and the broadening from 20: 1535 points to the presence of amorphous active silica [8]. 


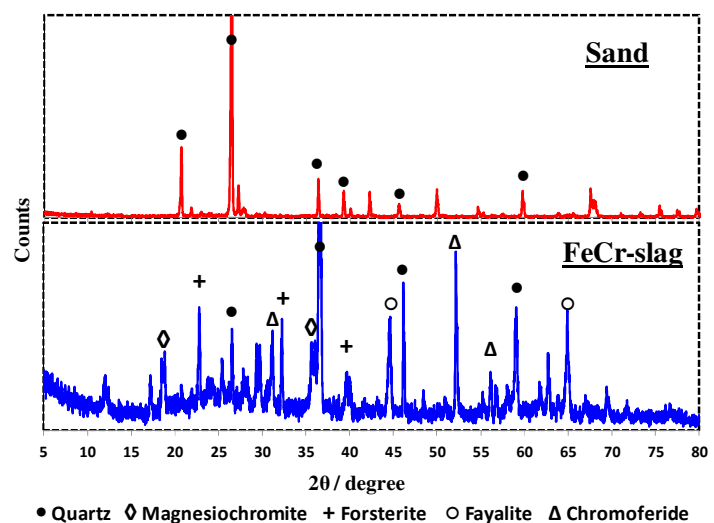

Fig. 2. XRD patterns of aggregates used (natural sand and FeCr-slag) [8].

From the physical properties test results it can be revealed that there are several potential uses of $\mathrm{FeCr}$ slag: 1) it can be used as an aggregate in concrete and hot mix asphalt and concrete pavements, 2) as a base or sub-base material, and 3) as an embankment and landfill material.

\section{Use of Ferrochrome (FeCr) Slag in concrete}

Very limited studies were conducted to study the effect of $\mathrm{FeCr}$ slag on the properties of cement mortars and concrete. These studies were focused mainly on the use of $\mathrm{FeCr}$ slag as aggregate substitute. Zelić [12] investigated the properties of concrete pavements prepared with ferrochromium slag as concrete aggregate. The results showed that the 28-day compressive strength of the concrete made with original un-fractioned slag and with standard limestone as aggregate reached the values of $57 \mathrm{MPa}$ and $36.7 \mathrm{MPa}$, respectively. The properties of concrete was investigated by Gencel et al. [13] under combined effects of fly ash as cement replacement and ferrochrome slag as aggregate substitute. Cement was replaced with fly ash at the ration of 10,20 , and $30 \mathrm{wt} \%$ whereas coarse limestone aggregates were replace with coarse ferrochromium aggregate at the ratio of 25,50 , and $75 \mathrm{wt} \%$. The results from the study revealed that ferrochromium aggregates increase the strength of concrete and also the abrasive wear resistance while it has negligible influence on the porosity and water absorption of concrete. A Study [6] which was carried out on the effect of microsilica addition within a low cement castables matrix of calcined bauxite and ferrochrome slag showed that slag containing castables achieved good thermal properties such as thermal shock resistance, permanent linear change, and pyrometric cone equivalent.

A number of researchers [16-19] studied the properties of normal and high strength concrete made with $\mathrm{FeCr}$ slag as an aggregate. The results indicated that replacement up to $75 \%$ of $\mathrm{FeCr}$ slag in lieu of fine aggregates improved the strength of concrete compared with conventional concrete. In a recent study, Acharya and Patro [15] investigated the effect of using ferrochrome ash (FCA) and lime dust in concrete properties. Up to $40 \%$ of FCA was used as cement substitution in concrete mixtures in four different substitutions at an interval of $10 \%$. FCA was modified with lime dust to enhance the performance of concrete in which substitution of lime was considered as $7 \%$ after studying its effect on blended cement based concrete. The results from Acharya and Patro study indicated that replacement of OPC up to $47 \%$ by FCA $(40 \%)$ and lime dust $(7 \%)$ has comparable positive impact on the 28 days strength and appreciable impact on long term strength properties.

The author and his colleagues [8] has recently studied the reuse of waste ferrochrome slag ( $\mathrm{FeCr}-\mathrm{Slag}$ ) generated from a chrome production plant in Sohar, Oman, as a partial replacement for sand in the production of cement mortars with improved thermal and mechanical properties. Sand was replaced by $\mathrm{FeCr}-\mathrm{Slag}$ in different percentages ranging from 0 up to $20 \%$ (by weight). Compressive strength, flexural strength, drying shrinkage, thermal conductivity and specific heat of the blended mortars were determined in accordance with ASTM standards at 3,7 and 28 days of curing. X-ray diffraction (XRD) was used to study the phase composition. The microstructure characteristics of the hardened samples were investigated by scanning electron microscope (SEM).The experimental results showed considerable improvements in both compressive and flexural strengths, enhancements of about 33 and $39 \%$, respectively were attained at $20 \% \mathrm{FeCr}$-Slag replacement after 28 days of curing. The drying shrinkage generally decreased with increasing replacements of sand by $\mathrm{FeCr}$ Slag. FeCr-slag acts to increase both the thermal conductivity and specific heat effectively. FeCr-slag led to noticeable modifications in the microstructure characteristics of the hardened blends. The results from the study are presented in figures 3-5.
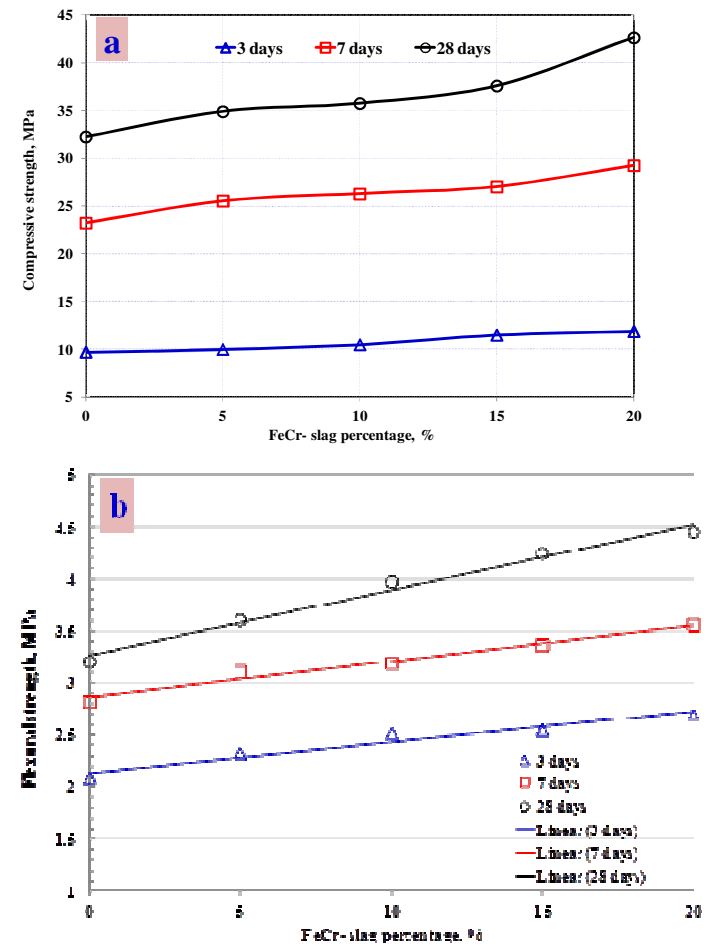

Fig. 3. Variations in the (a) compressive strength and (b) flexural strength of cement mortars incorporating $0,5,10,15$ and $20 \%$ FeCr-slag hydrated for 3, 7 and 28 days [8]. 


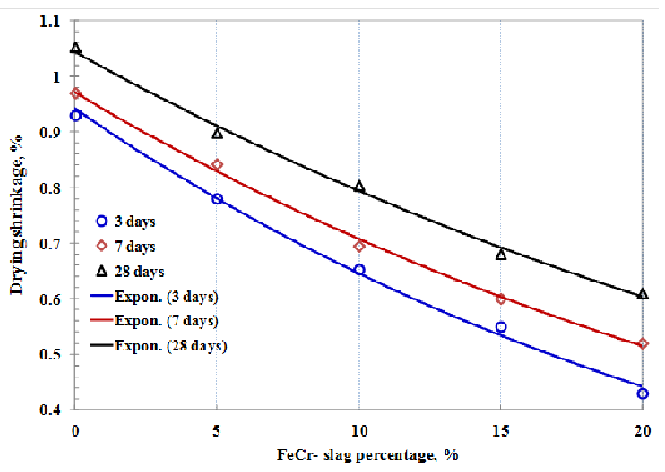

Fig. 4. . Variations in drying shrinkage of cement mortars incorporating $0,5,10,15$ and $20 \% \mathrm{FeCr}$-slag hydrated for 3,7 and 28 days [8].

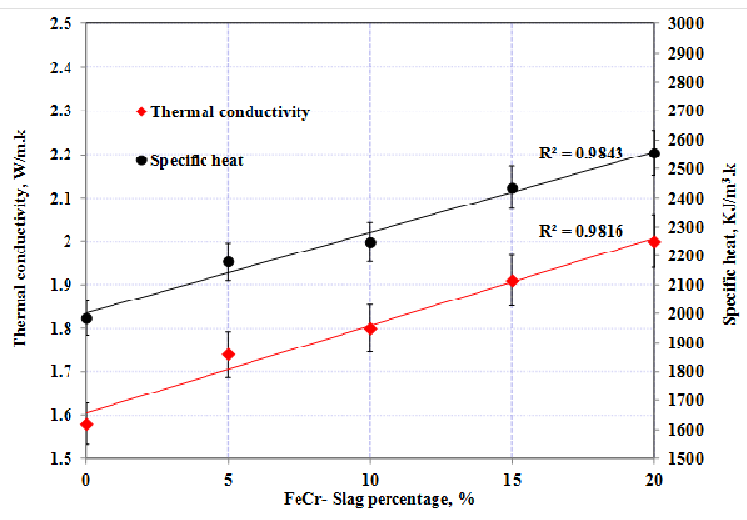

Fig. 5. Variations in thermal conductivity and specific heat of the cement mortars incorporating $0,5,10,15$ and $20 \%$ FeCr-slag at 28 days of hydration [8].

\section{Application of Ferrochrome (FeCr) Slag in Road Construction}

Different types of slag find wide acceptance in road construction industry as an aggregate in flexible and rigid pavements, hot asphalt mixes and as a material in base and sub-base layers. Slags possess superior properties such as volume stability, high volume mass, good abrasion resistance to wear and crushability which make it a suitable material for road construction [12]. The first use of slag as an aggregate in asphalt mixtures dates back to 1969 [11], when a trial road section was built in Toronto, on which steel slag was used as an aggregate in base course and road asphalt surfaces. The studied asphalt mixtures have demonstrated very good properties in terms of bearing capacity, resistance to external impacts, and durability.

In the last decade, the potential application of $\mathrm{FeCr}$ as an alternative aggregate in pavements and road construction has been investigated [2], [3], [5], [7], [12], [14], [21]. In 2001, Lind et al. [2] investigated the environmental impact of $\mathrm{FeCr}$ slag in road construction. The results indicated that $\mathrm{FeCr}$ slag is safe to use as a material in road construction. The study conducted by Zelić [12] on the use of $\mathrm{FeCr}$ slag as concrete aggregate in concrete pavement concluded that the reinforced slag concrete is suitable for wearing courses of concrete pavements for traffic classes 1 and 2 where carbonate stone material does not meet the standard technical requirements for cement concrete slab pavements according to the Croatian standard. Yilmaz and Karaşahin [5] studied the mechanical properties of $\mathrm{FeCr}$ slag in granular layers of flexible pavements. The experimental program consisted of two parts: 1) study of the physical and chemical properties of slag, and 2) study of the mechanical properties of specimens made with $\mathrm{FeCr}$ slag and limestone as aggregate. Test results indicated that the physical properties of the slag such as the LA and CBR values, and high frost resistance meet the requirements of the aggregates for granular layers of flexible pavements which qualify $\mathrm{FeCr}$ slag as aggregate suitable for pavement layers. In another stud, the authors [14] verified that mixtures of $\mathrm{FeCr}$ slag and Portland cement and $\mathrm{FeCr}$ and silica fume can be utilized as a road base layer material in specific mixture ratio. The study recommended conducting field tests to verify the slag use in cement-bound layers of pavements. The potential use of FeCr slag as an embankment and granular subbase was evaluated by Das [21].

The use of $\mathrm{FeCr}$ slag as an aggregate in road construction is practiced in many countries such as Finland, Sweden, South Africa and India [4]. Finland is one of the leading countries in the world that utilizes $\mathrm{FeCr}$ slag commercially in road construction industry [20]. The FeCr slag products have been used in Finland since early seventies for many different purposes [3]. Outokumpu [20], Finland is the major producer of $\mathrm{FeCr}$ slag, used the $\mathrm{FeCr}$ slag in road construction as shown in figure 6. Due to its superior physical properties over the natural aggregates, roads can be built with thinner bases and sub-bases than when using natural aggregates (figure 7) [4]. $\mathrm{FeCr}$ slag has similar applications in other countries such as India, Sweden, and South Africa.

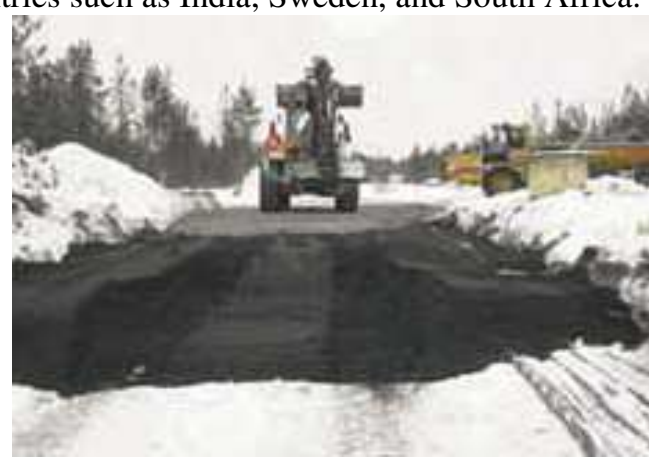

Fig. 6. Use of $\mathrm{FeCr}$ slag in road construction in Finland [20].

The outcomes from the previous studies concluded that $\mathrm{FeCr}$ slag have the potential to be utilized as a pavement base layer material in similar applications where traditional natural aggregates are used. It can also be used as a base or sub-base material in highway pavements and as an embankment material. The use of $\mathrm{FeCr}$ slag as aggregate in pavement layers reduces the requirement for natural aggregates and saves the existing natural resources. 


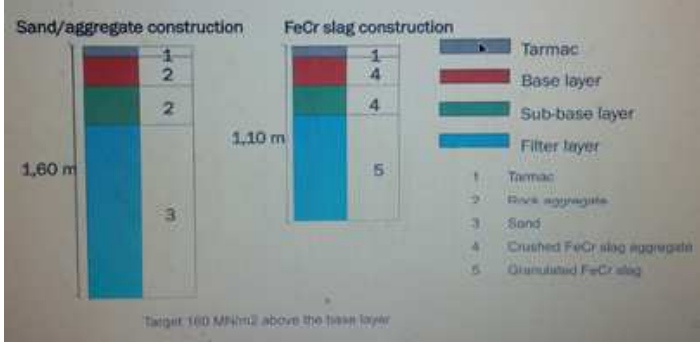

Fig. 7. The advantage of using $\mathrm{FeCr}$ slag in road construction [4].

\section{FeCr Slag, Is It Environmentally Safe?}

Chemical analysis on various $\mathrm{FeCr}$ slag samples have detected traces of heavy metals specially chromium oxide, Cr (VI) [2-4], [6-7], [11], [14], [17]. The waste slag contains about $6-12 \%$ chromium as chromium oxide and it has the potentiality of releasing hazardous chromium compounds. The $\mathrm{Cr}$ (VI) compounds are very toxic and highly leachable. This leaching characteristic may classify the slag as hazardous waste and restricts its use and disposal. To evaluate the potential hazards that may arise from the use of $\mathrm{FeCr}$ slag, leaching tests was conducted by various researchers according to the Synthetic Precipitation Leaching Procedure (SPLP). The results confirmed that the $\mathrm{FeCr}$ slag is not pollutant and it can be used safely. In all studies, the SPLP test results demonstrated that except for the $\mathrm{Cr}(\mathrm{VI})$, the leaching of other heavy elements is negligible in terms of environmental impact. The $\mathrm{Cr}$ (VI) concentrations were slightly above target for inert waste meet the US EPA limits of $5 \mathrm{mg} / \mathrm{l}$ for chromium [22]. This implies that $\mathrm{FeCr}$ slag is not classified as a hazardous substance with respect to chromium. An environmental impact study on $\mathrm{FeCr}$ slag in road construction was conducted by Lind et al. [2]. The results from an in situ leachate test revealed that there was a low migration of particles from the slag to the underlying soil and that the leaching into the groundwater was also low for all the elements analysed.

\section{Conclusions}

This paper presented an overview of the recent research on the use of ferrochrome slag in various civil engineering applications such as road construction, and cement and concrete industries. The study concluded that the physical and mechanical properties of $\mathrm{FeCr}$ are as good or better than those of natural aggregate which make it suitable material to be used as aggregate replacement in concrete and road construction applications such as in rigid and flexible pavements and base or sub-base materials. Environmental impact assessment studies proved that $\mathrm{FeCr}$ slag is nonhazardous material and environmentally friendly to be used as a green construction material in lieu of natural aggregates.

Waste is a source of secondary raw materials but at the same time can negatively impact the natural environment and public health. The production of industrial by-products in Oman is expected to increase rapidly in the coming few years due to the industrial development in the country which will have a detrimental impact on the environment unless waste management policies and legislations are developed. Successful utilization of industrial by-products in the construction industry would require more detailed economic and environmental analyses as well as engineering design specifications.

\section{References}

1. N. Su, Z. Chen, H. Fang, Cem. Concr. Comp. 23 (2001)

2. B.B. Lind, A.M. Fallman, L.B. Larsson, Waste Manage. 21 (2001)

3. P. Niemelä, M. Kauppi, INFACON XI (2007)

4. A. Das, M. Lobo, AL TAMMAN INDSIL FERRO CHROME LLC (unpublished presentation) (2017)

5. A. Yilmaz, M. Karaşahin, Mater Struct 43 (2010)

6. P.H. Kumar, A. Srivastava, V. Kumar, M.R. Majhi, V.K. Singh, J. Asian Ceram. Soc. 2 (2014)

7. P. Chittaranjan, PhD Thesis (2015)

8. K. Al-Jabri, H. Shoukry, I.S. Khalil, S. Nasir, H.F. Hassan, J. Mater. Civil Eng. (under review)

9. J. Zhang, Ch. Gong, L. Lu, W. Shoude, P. Hou, Ceramics - Silikáty 59, 2 (2015)

10. I. Zheng, C. Xuehua, T. Mingshu, J. Cem. Concr. Res. 22 (1992)

11. I. Barišić, S. Dimter, I. Netinger, Technical Gazette 17, 4 (2010)

12. J. Zelić, Cem. Concr. Res. 35 (2005)

13. O. Gencel, F. Koksal, C. Ozel, W. Brostow, Constr. Build. Mater. 29 (2012)

14. A. Yilmaz, M. Karaşahin, Turkish J Eng Env Sci 37 (2013)

15. P.K. Acharya, S.K. Patro, J. Clean. Prod., 131 (2016)

16. M. Nadeen, A.D. Pofale, Open Journal of Civil Engineering 2 (2012).

17. C.R. Panda, K.K. Mishra, K.C. Panda, B.D. Nayak, B.B. Nayak, Constr Build Mater 49 (2013)

18. S.M. Susheel, S.R. Sathwik, T. Vinayak, S. Darshan, J. Sanjith, A. Ranjith, IJISET 3, 6 (2016)

19. S.R. Sathwik, J. Sanjith, G.N. Sudhakar, AJER 5, 9 (2016)

20. V. Kallio, T. Holappa, A. Tikkakoski, Outokumpu Report, $\quad$ http://www.morenia.fi/wpcontent/uploads/sites/7/2015/02/OKTO_rakennustuo tteet_eng.pdf (accessed 20/06/2017).

21. B.B. Das, MSc Thesis, National Institute of Technology Rourkela (2014)

22. W.A. Gericke, INFACON7 (1995) 